\title{
Pneumonia pada Anak Balita di Indonesia
}

\section{Pneumonia among Children Under Five Years of Age in Indonesia}

\author{
Athena Anwar, Ika Dharmayanti
}

\section{Pusat Teknologi Intervensi Kesehatan Masyarakat Badan Penelitian dan Pengembangan Kesehatan Kementerian Kesehatan RI}

\begin{abstract}
Abstrak
Pneumonia adalah penyakit infeksi yang merupakan penyebab utama kematian pada balita di dunia. Riset Kesehatan Dasar (Riskesdas) tahun 2007 melaporkan bahwa kematian balita di Indonesia mencapai 15,5\%. Penelitian ini bertujuan untuk mengidentifikasi faktor determinan terjadinya pneumonia pada balita di Indonesia. Desain penelitian ini adalah potong lintang dengan menggunakan data Riskesdas 2013. Kriteria sampel adalah balita ( 0 - 59 bulan) yang menjadi responden Riskesdas 2013. Variabel dependen adalah kejadian pneumonia balita, sedangkan variabel independennya adalah karakteristik individu, lingkungan fisik rumah, perilaku penggunaan bahan bakar, dan kebiasaan merokok. Penetapan kejadian pneumonia berdasarkan hasil wawancara, dengan batasan operasional diagnosis pneumonia oleh tenaga kesehatan dan/atau dengan gejala pneumonia dalam periode 12 bulan terakhir. Jumlah sampel yang memenuhi kriteria adalah 82.666 orang. Hasil menunjukkan bahwa faktor risiko yang paling berperan dalam kejadian pneumonia balita adalah jenis kelamin balita (OR $=1,10 ; 95 \% \mathrm{Cl}=1,02-1,18)$, tipe tempat tinggal $(\mathrm{OR}=1,15 ; 95 \% \mathrm{Cl}=1,06$ $-1,25)$, pendidikan ibu $(\mathrm{OR}=1,20 ; 95 \% \mathrm{Cl}=1,11-1,30)$, tingkat ekonomi keluarga/kuintil indeks kepemilikan $(\mathrm{OR}=1,19 ; 95 \% \mathrm{Cl}=1,10-1,30)$, pemisahan dapur dari ruangan lain $(\mathrm{OR}=1,19 ; 95 \% \mathrm{Cl}=1,05-1,34)$, keberadan/kebiasaan membuka jendela kamar $(\mathrm{OR}=1,17 ; 95 \% \mathrm{Cl}=1,04-$ $1,31)$, dan ventilasi kamar yang cukup $(\mathrm{OR}=1,16 ; 95 \% \mathrm{Cl}=1,04-1,30)$. Disimpulkan bahwa faktor sosial, demografi, ekonomi dan kondisi lingkungan fisik rumah secara bersama-sama berperan terhadap kejadian pneumonia pada balita di Indonesia.
\end{abstract}

Kata kunci: Balita, kondisi lingkungan fisik rumah, pneumonia

\section{Abstract}

Pneumonia is an infectious disease which is a major cause of mortality in children under five years of age in the world. National Basic Health Research 2007 reported that infant mortality in Indonesia has reached $15.5 \%$. The objective of the study was to identify the determinant factors related to the incidence of pneumonia in children under five years of age in Indonesia. The research design was cross sectional, using National Basic Health Research 2013 data. Sample criteria were children under five years of age ( 0 - 59 months). The dependent variable was the incidence of pneumonia among children under five years of age, while the independent variables were individual characteristics, physical environment of house, types of fuel used, and smoking habit. There were 82,666 samples that fulfilled the study criteria. The result showed that determinant factors contributing to the incidence of pneumonia in children were $\operatorname{sex}(O R=1.10 ; 95 \% \mathrm{Cl}=1.02-$ 1.18), residence (urban/rural) $(\mathrm{OR}=1.15 ; 95 \% \mathrm{Cl}=1,06-1,25)$, maternal education $(\mathrm{OR}=1.20 ; 95 \% \mathrm{Cl}=1.11-1.30)$, household poverty index quintile $(O R=1.19 ; 95 \% \mathrm{Cl}=1.10-1.30)$, kitchen separation $(\mathrm{OR}=1.19 ; 95 \%$ $\mathrm{Cl}=1.05-1.34)$, window availability in bedroom $(\mathrm{OR}=1.17 ; 95 \% \mathrm{Cl}=1.04$ $-1.31)$, and bedroom ventilation $(\mathrm{OR}=1.16 ; 95 \% \mathrm{Cl}=1.04-1.30)$. This study concluded that social factors, demographic, economic levels and the physical environment of house simultaneously contributed to the incidence of pneumonia in children under five of age.

Keywords: Children under five years of age, physical environment of house, pneumonia

\section{Pendahuluan}

Sampai saat ini, penyakit pneumonia merupakan penyebab utama kematian balita di dunia. Diperkirakan ada 1,8 juta atau $20 \%$ dari kematian anak diakibatkan oleh pneumonia, melebihi kematian akibat AIDS, malaria dan tuberkulosis. ${ }^{1}$ Di Indonesia, pneumonia juga merupakan urutan kedua penyebab kematian pada balita setelah diare. Riset Kesehatan Dasar (Riskesdas) mela-

Alamat Korespondensi: Athena Anwar, Pusat Teknologi Intervensi Kesehatan Masyarakat Balitbangkes Kemenkes RI, Jl. Percetakan Negara No. 29 Jakarta Pusat 10560,Hp.08121033725,e-mail: athenafb@yahoo.com 
porkan bahwa kejadian pneumonia sebulan terakhir ( $p e$ riod prevalence) mengalami peningkatan pada tahun 2007 sebesar 2,1\%o menjadi 2,7 \%o pada tahun 2013. Kematian balita yang disebabkan oleh pneumonia tahun 2007 cukup tinggi, yaitu sebesar 15,5\%.2,3 Demikian juga hasil Survei Demografi dan Kesehatan Indonesia (SD$\mathrm{KI}$ ), yang melaporkan bahwa prevalensi pneumonia dari tahun ke tahun terus meningkat, yaitu 7,6\% pada tahun 2002 menjadi $11,2 \%$ pada tahun 2007.4

Menurut definisi, pneumonia adalah infeksi jaringan paru-paru (alveoli) yang bersifat akut. Penyebabnya adalah bakteri, virus, jamur, pajanan bahan kimia atau kerusakan fisik dari paru-paru, maupun pengaruh tidak langsung dari penyakit lain. Bakteri yang biasa menyebabkan pneumonia adalah Streptococcus dan Mycoplasma pneumonia, sedangkan virus yang menyebabkan pneumonia adalah adenoviruses, rhinovirus, influenza virus, respiratory syncytial virus (RSV) dan para influenza virus.

Terjadinya pneumonia ditandai dengan gejala batuk dan atau kesulitan bernapas seperti napas cepat, dan tarikan dinding dada bagian bawah ke dalam. ${ }^{5}$ Pada umumnya, pneumonia dikategorikan dalam penyakit menular yang ditularkan melalui udara, dengan sumber penularan adalah penderita pneumonia yang menyebarkan kuman dalam bentuk droplet ke udara pada saat batuk atau bersin. Untuk selanjutnya, kuman penyebab pneumonia masuk ke saluran pernapasan melalui proses inhalasi (udara yang dihirup), atau dengan cara penularan langsung, yaitu percikan droplet yang dikeluarkan oleh penderita saat batuk, bersin, dan berbicara langsung terhirup oleh orang di sekitar penderita, atau memegang dan menggunakan benda yang telah terkena sekresi saluran pernapasan penderita. ${ }^{6}$

Banyak faktor yang dapat berpengaruh terhadap meningkatnya kejadian pneumonia pada balita, baik dari aspek individu anak, perilaku orang tua (ibu), maupun lingkungan. Kondisi lingkungan fisik rumah yang tidak memenuhi syarat kesehatan dan perilaku penggunaan bahan bakar dapat meningkatkan risiko terjadinya berbagai penyakit seperti TB, katarak, dan pneumonia. ${ }^{7-9} \mathrm{Ru}-$ mah yang padat penghuni, pencemaran udara dalam ruang akibat penggunaan bahan bakar padat (kayu bakar/ arang), dan perilaku merokok dari orangtua merupakan faktor lingkungan yang dapat meningkatkan kerentanan balita terhadap pneumonia. ${ }^{6}$

Proporsi penduduk di Indonesia yang tinggal di rumah yang memenuhi persyaratan rumah sehat masih rendah, yaitu 24,9\%. ${ }^{10}$ Menurut laporan Riskesdas 2013, penduduk yang tinggal di rumah dengan atap rumah berplafon hanya $59,4 \%$, dinding terbuat dari tembok hanya $69,6 \%$, dan lantai bukan tanah 93,1\%.3 Perilaku yang dapat menimbulkan risiko pencemaran udara dalam ruang, seperti penggunaan bahan bakar yang tidak aman (minyak tanah, kayu bakar, arang, batu bara) dan kebiasaan merokok di dalam rumah, proporsinya masih cukup tinggi. Sebanyak $64,2 \%$ rumah tangga di perdesaan masih menggunakan arang dan kayu bakar untuk memasak dan 76,6\% (dari 28,2\% perokok) merokok di dalam rumah ketika bersama dengan anggota keluarga lainnya. ${ }^{3}$

Berdasarkan permasalahan tersebut, perlu diteliti lebih lanjut faktor apa saja yang dapat berpengaruh terhadap kejadian pneumonia pada balita di Indonesia. Penelitian ini bertujuan untuk mengidentifikasi faktor determinan yang berperan dalam pneumonia pada balita di Indonesia.

\section{Metode}

Penelitian ini bersifat deskriptif analitis dilakukan dengan desain potong lintang, menggunakan data Riskesdas 2013, Badan Penelitian dan Pengembangan Kesehatan, Kementerian Kesehatan Republik Indonesia. Kriteria sampel adalah balita ( 12 - 59 bulan) yang menjadi responden Riskesdas 2013. Variabel dependen adalah kejadian pneumonia balita, sedangkan variabel independennya adalah karakteristik individu, lingkungan fisik rumah, perilaku penggunaan bahan bakar, dan kebiasaan merokok. Kriteria inklusi adalah anak balita ( 0 59 bulan).

Penetapan kejadian pneumonia didasarkan pada hasil wawancara terhadap ibu balita, dengan batasan operasional diagnosis pneumonia oleh tenaga kesehatan dan/atau dengan gejala pneumonia dalam periode $12 \mathrm{bu}$ lan terakhir. Jumlah sampel balita yang memenuhi kriteria adalah 82.666 orang. Analisis data dilakukan secara univariat, bivariat, dan multivariat. Analisis bivariat digunakan untuk mengetahui sejauh mana hubungan antara faktor-faktor yang diduga berhubungan dengan kejadian pneumonia (odds ratio) dilakukan dengan uji kai kuadrat menggunakan tingkat kemaknaan (nilai p) 0,05 dan derajat kepercayaan (confidence interval) 95\%.

Untuk melihat faktor determinan pneumonia pada balita, dilakukan analisis multivariat regresi logistik ganda (multiple logistic regression) terhadap variabel hasil analisis bivariat yang mempunyai nilai $p$ kurang dari 0,25 atau secara subtansi dianggap penting berhubungan terhadap kejadian pneumonia pada balita.

\section{Hasil}

Terdapat 1.229 orang $(1,5 \%)$ pernah didiagnosis petugas kesehatan dan 2.091 orang $(2,5 \%)$ mengalami gejala pneumonia dalam 12 bulan terakhir sejak wawancara dilakukan (Tabel 1). 81.205 orang tidak pernah didiagnosis $(98,2 \%)$ dan 232 orang tidak tahu $(0,3 \%)$. Sebanyak 79.233 orang $(95,8 \%)$ tidak mengalami gejala pneumonia dan 115 orang $(0,1 \%)$ menyatakan tidak tahu. 
Kejadian pneumonia pada anak balita adalah berdasarkan diagnosis oleh petugas kesehatan maupun gejala yang dirasakan/diamati, yaitu berjumlah 3.320 orang $(4,0 \%)$ (Tabel 1).

Berdasarkan karakteristik sosiodemografi, karakteristik individu dengan kejadian pneumonia pada jenis kelamin antara laki-laki dan perempuan hampir sama, lakilaki sebanyak 41.925 hanya berselisih lebih tinggi sedikit daripada perempuan, yaitu sebanyak 40.695. Tempat tinggal balita lebih banyak di perdesaan dibanding perkotaan, pendidikan ibu balita pada umumnya SLTP ke atas. Ibu balita yang tidak bekerja lebih banyak hampir setengah dari ibu yang bekerja. Tingkat ekonomi rumah tangga balita yang diukur berdasarkan kuintil indeks kepemilikan, lebih banyak berada di tingkat menengah ke atas (menengah sampai teratas) dibanding menengah ke bawah (menengah bawah dan terbawah) (Tabel 2).

Berdasarkan bahan bangunan dan kondisi kesehatan lingkungan fisik rumah, jenis lantai rumah balita pada umumnya adalah bukan tanah (keramik/ubin/marmer/ semen), dinding rumah lebih banyak terbuat dari tembok, atap tanpa plafon/langit-langit, dan masih terdapat rumah dengan kamar tidak berjendela/tidak biasa membuka jendela. Untuk kondisi ruangan rumah, lebih banyak balita tinggal di rumah dengan dapur terpisah dengan ruangan lain, ventilasi kamar pada umumnya tidak cukup $(<10 \%$ luas lantai) tetapi pencahayaan alami kamar pada umumnya cukup. Lebih banyak balita tinggal

Tabel 1. Distribusi Balita Menurut Kejadian Pneumonia

\begin{tabular}{llll}
\hline Kejadian Pneumonia & Kategori & $\mathbf{n}$ & $\%$ \\
\hline Didiagnosis pneumonia & Ya & 1.229 & 1,5 \\
& Tidak & 81.205 & 98,2 \\
& Tidak tahu & 232 & 0,3 \\
Gejala demam, batuk, & Ya & 2.091 & 2,5 \\
sulit bernapas & Tidak & 79.233 & 95,8 \\
& Tidak tahu & 113 & 0,1 \\
\hline
\end{tabular}

di rumah padat huni (kurang dari $8 \mathrm{~m}^{2} /$ orang) (Tabel 3).

Menurut perilaku penggunaan bahan bakar, sepertiga rumah tangga balita menggunakan bahan bakar yang dapat menimbulkan pencemaran udara (arang/batu bara/ batok kelapa, dan kayu bakar). Menurut perilaku merokok, dari seluruh anggota rumah tangga biasa merokok, lebih banyak yang merokok di dalam rumah ketika bersama anggota rumah tangga lain.

Risiko pneumonia meningkat secara bermakna (nilai $\mathrm{p}<0,05)$ pada kelompok balita laki-laki $(\mathrm{OR}=1,11)$, pada kelompok yang bertempat tinggal di pedesaan (OR $=1,29$ ), pada kelompok ibu balita dengan pendidikan SD ke bawah $(\mathrm{OR}=1,49)$, dan pada kelompok tingkat ekonomi keluarga menengah bawah $(\mathrm{OR}=1,44)$. Tabel 3 menunjukkan bahwa risiko pneumonia meningkat secara bermakna (nilai $p<0,05$ ) pada kelompok balita yang tinggal di rumah dengan jenis lantai tanah $(\mathrm{OR}=$ $1,36)$, jenis dinding bukan tembok $(\mathrm{OR}=1,27)$, atap rumah tidak berplafon/langit-langit $(\mathrm{OR}=1,12)$, tidak memiliki/tidak biasa membuka jendela kamar tidur (OR $=1,38)$, dapur yang tidak terpisah dengan ruangan lain $(\mathrm{OR}=1,40)$, ventilasi dan pencahayaan kamar tidak cukup $(\mathrm{OR}=1,38)$, padat penghuni $(\mathrm{OR}=1,21)$, menggunakan bahan bakar memasak yang tidak aman $(\mathrm{OR}=$ 1,30) (Tabel 3).

Variabel yang masuk dalam analisis multivariat adalah umur, jenis kelamin, dan tipe tempat tinggal balita, pendidikan ibu, tingkat ekonomi/kuintil indeks kepemilikan rumah tangga, jenis lantai, jenis dinding, keberadaan plafon/langit-langit rumah, keberadaan jendela kamar, ruang dapur (terpisah/tidak terpisah dari ruangan lain), ventilasi, dan pencahayaan kamar tidur, kepadatan hunian, dan penggunaan bahan bakar.

Hasil analisis hubungan multivariat antara faktor risiko pneumonia dengan kejadian pneumonia pada balita, diperoleh tujuh variabel yang menunjukkan risiko yang bermakna (nilai $p<0,05$ ). Risiko ketujuh variabel

Tabel 2. Hubungan Karakteristik Individu dengan Kejadian Pneumonia

\begin{tabular}{|c|c|c|c|c|c|c|c|c|c|}
\hline \multirow{3}{*}{ Karakteristik } & \multirow{3}{*}{ Kategori } & \multirow{3}{*}{ Jumlah } & \multicolumn{4}{|c|}{ Pneumonia } & \multirow{3}{*}{ OR } & \multirow{3}{*}{ 95\% CI } & \multirow{3}{*}{ Nilai $p$} \\
\hline & & & \multicolumn{2}{|c|}{ Ya } & \multicolumn{2}{|c|}{ Tidak } & & & \\
\hline & & & $\mathbf{n}$ & $\%$ & $\mathbf{n}$ & $\%$ & & & \\
\hline Umur balita & Bayi & 15.609 & 451 & 2,9 & 15.159 & 97,1 & 0,67 & $0,61-0,74$ & 0,000 \\
\hline Jenis kelamin balita & Perempuan & 40.693 & 1.550 & 3,8 & 39.143 & 96,2 & & & \\
\hline \multirow[t]{2}{*}{ Tipe tempat tinggal } & Perdesaan & 45.641 & 1.852 & 4,5 & 39.208 & 95,5 & 1,29 & $1,2-1,38$ & 0,000 \\
\hline & Perkotaan & 37.025 & 1.468 & 3,5 & 40.138 & 96,5 & & & \\
\hline \multirow[t]{2}{*}{ Pendidikan ibu } & SD ke bawah & 30.449 & 1.487 & 4,9 & 28.964 & 95,1 & 1,49 & $1,32-1,52$ & 0,000 \\
\hline & SLTP ke atas & 48.869 & 1.706 & 3,5 & 47.164 & 96,5 & & & \\
\hline
\end{tabular}


Tabel 3. Hubungan Karakteristik Rumah, Perilaku Penggunaan Bahan Bakar, dan Merokok Anggota Rumah Tangga dengan Kejadian Pneumonia

\begin{tabular}{|c|c|c|c|c|c|c|c|c|c|}
\hline \multirow{3}{*}{ Karakteristik } & \multirow{3}{*}{ Kategori } & \multirow{3}{*}{ Jumlah } & \multicolumn{4}{|c|}{ Pneumonia } & \multirow{3}{*}{ OR } & \multirow{3}{*}{$95 \% \mathrm{CI}$} & \multirow{3}{*}{ Nilai $p$} \\
\hline & & & \multicolumn{2}{|c|}{ Ya } & \multicolumn{2}{|c|}{ Tidak } & & & \\
\hline & & & n & $\%$ & n & $\%$ & & & \\
\hline \multirow[t]{2}{*}{ Jenis lantai } & Tanah & 5.033 & 265 & 5,3 & 4.769 & 94,7 & 1,36 & $1,19-1,54$ & 0,000 \\
\hline & Bukan tanah & 77.632 & 3.055 & 3,9 & 74.578 & 96,1 & & & \\
\hline \multirow[t]{2}{*}{ Jenis dinding } & Bukan tembok & 26.629 & 1.243 & 4,7 & 25.386 & 95,3 & 1,27 & $1,18-1,37$ & 0,000 \\
\hline & Tembok & 56.037 & 2.077 & 3,7 & 53.960 & 96,3 & & & \\
\hline \multirow[t]{2}{*}{ Plafon/langit-langit } & Tidak berplafon & 34.512 & 1.479 & 4,3 & - & 95,7 & 1,12 & $1,05-1,21$ & 0,000 \\
\hline & Berplafon & 48.154 & 1.840 & 3,8 & 46.314 & 96,2 & & & \\
\hline \multirow[t]{2}{*}{ Keberadaan jendela kamar } & Tidak ada & 13.229 & 531 & 5,2 & 9.619 & 94,8 & 1,38 & $1,25-1,51$ & 0,000 \\
\hline & Ada & 69.430 & 2.788 & 3,8 & 69.722 & 96,2 & & & \\
\hline \multirow{2}{*}{ Dapur terpisah } & Tidak & 6.280 & 338 & 5,4 & 5.942 & 94,6 & 1,40 & $1,25-1,57$ & 0,000 \\
\hline & Ya & 76.386 & 2.981 & 3,9 & 73.405 & 96,1 & & & \\
\hline \multirow[t]{2}{*}{ Ventilasi kamar } & Tidak cukup & 47.608 & 523 & 5,2 & 9.485 & 94,8 & 1,38 & $1,25-1,51$ & 0,000 \\
\hline & Cukup & 35.051 & 2795 & 3,8 & 69.856 & 96,2 & & & \\
\hline \multirow[t]{2}{*}{ Pencahayaan kamar } & Tidak cukup & 24.935 & 848 & 4,8 & 16.698 & 95,2 & 1,29 & $1,19-1,39$ & 0,000 \\
\hline & Cukup & 57.724 & 2.470 & 3,8 & 62.643 & 96,2 & & & \\
\hline \multirow[t]{2}{*}{ Kepadatan hunian } & Padat & 64.545 & 836 & 4,6 & 17.285 & 95,4 & 1,21 & $1,11-1,31$ & 0,000 \\
\hline & Tidak padat & 18.121 & 2484 & 3,8 & 62.061 & 96,2 & & & \\
\hline \multirow[t]{2}{*}{ Bahan bakar } & Tidak aman & 21.830 & 1.321 & 4,7 & 1.316 & 95,3 & 1,30 & $1,21-1,40$ & 0,000 \\
\hline & Aman & 60.836 & 2.018 & 3,7 & 2.014 & 96,3 & & & \\
\hline \multirow{2}{*}{ ART merokok dalam rumah } & $\mathrm{Ya}$ & 45.370 & 1.883 & 4,2 & 43.487 & 95,8 & 1,04 & $0,94-1,14$ & 0,498 \\
\hline & Tidak & 12.935 & 519 & 4,0 & 12.416 & 96 & & & \\
\hline
\end{tabular}

Tabel 4. Analisis Multivariat Faktor Risiko Pneumonia dengan Kejadian Pneumonia Balita

\begin{tabular}{|c|c|c|c|c|c|c|}
\hline \multirow{2}{*}{ Variabel } & \multirow{2}{*}{ Kategori } & \multicolumn{2}{|c|}{ Pneumonia (\%) } & \multirow{2}{*}{ OR } & \multirow{2}{*}{$95 \%$ CI } & \multirow{2}{*}{ Nilai $p$} \\
\hline & & Ya & Tidak & & & \\
\hline \multirow[t]{2}{*}{ Jenis kelamin balita } & Laki-laki & 4,2 & 95,8 & 1,10 & $1,02-1,18$ & 0,010 \\
\hline & Perempuan & 3,8 & 96,2 & & & \\
\hline \multirow[t]{2}{*}{ Tipe tempat tinggal } & Perdesaan & 4,5 & 95,5 & 1,15 & $1,06-1,25$ & 0,000 \\
\hline & Perkotaan & 3,5 & 96,5 & & & \\
\hline \multirow[t]{2}{*}{ Pendidikan ibu } & SD ke bawah & 4,9 & 95,1 & 1,20 & $1,11-1,30$ & 0,000 \\
\hline & SLTP ke atas & 3,5 & 96,5 & & & \\
\hline \multirow[t]{2}{*}{ Kuintil indeks kepemilikan } & Menengah bawah & 5,0 & 95,0 & 1,19 & $1,10-1,30$ & 0,000 \\
\hline & Menengah atas & 3,5 & 96,5 & & & \\
\hline \multirow[t]{2}{*}{ Dapur terpisah } & Tidak & 5,4 & 94,6 & 1,19 & $1,05-1,34$ & 0,010 \\
\hline & Ya & 3,9 & 96,1 & & & \\
\hline \multirow[t]{2}{*}{ Jendela kamar } & Tidak ada & 5,2 & 94,8 & 1,17 & $1,04-1,31$ & 0,010 \\
\hline & Ada & 3,8 & 96,2 & & & \\
\hline \multirow[t]{2}{*}{ Ventilasi kamar } & Ya & 5,2 & 94,8 & 1,16 & $1,04-1,30$ & 0,010 \\
\hline & Tidak & 3,8 & 96,2 & & & \\
\hline
\end{tabular}

tersebut tidak banyak berubah dari hasil analisis secara bivariat. Variabel tersebut adalah jenis kelamin balita, tipe tempat tinggal, pendidikan ibu, kuintil indeks kepemilikan, dapur terpisah, jendela kamar, dan ventilasi kamar.

Faktor perilaku penggunaan bahan bakar maupun merokok di dalam rumah ketika bersama ART lain, menjadi tidak bermakna $(\mathrm{p} \geq 0,05)$ (Tabel 4$)$.

\section{Pembahasan}

Dari hasil uji multivariat diperoleh tujuh faktor risiko secara bersama-sama berhubungan secara bermakna dengan pneumonia pada balita (nilai $\mathrm{p}<0,05$ ), yaitu jenis kelamin balita, tipe tempat tinggal, pendidikan ibu, tingkat ekonomi/kuintil indeks kepemilikan, kondisi rumah letak dapur, keberadaan/kebiasaan membuka jendela dan ventilasi kamar tidur. Risiko pneumonia balita yang ibunya berpendidikan rendah (SD ke bawah) lebih tinggi dibandingkan dengan ibu yang berpendidikan lebih tinggi $(\mathrm{OR}=1,20)$. Demikian juga risiko pneumonia balita pada rumah tangga dengan tingkat ekonomi rendah (menengah dan terbawah) lebih tinggi dibandingkan dengan tingkat ekonomi tinggi (menengah atas sampai teratas) $(\mathrm{OR}=1,19)$. Hal ini dimungkinkan karena rumah tangga dengan status ekonomi yang lebih tinggi dapat memiliki kemampuan lebih baik dalam 
pemenuhan kebutuhannya, termasuk pemeliharaan kesehatan (meningkatkan akses terhadap pelayanan kesehatan dan ibu yang berpendidikan lebih tinggi diharapkan mempunyai informasi dan wawasan yang lebih baik termasuk dalam pemecahan masalah kesehatan.

Apabila dibandingkan dengan penelitian/kajian yang telah dilakukan sebelumnya, yang dilakukan oleh Mosley dan Chen, ${ }^{11}$ hasil penelitian ini tidak jauh berbeda. Hasil penelitian tersebut menyatakan bahwa status ekonomi rumah tangga dan pendidikan secara tidak langsung berpengaruh terhadap kesehatan. ${ }^{11}$ Demikian juga apabila dibandingkan dengan hasil penelitian Hananto, 12 yang menunjukkan bahwa status ekonomi dan tingkat pendidikan berhubungan dengan kejadian penyakit pneumonia balita. Hasil penelitian ini juga tidak jauh berbeda dengan hasil penelitian Machmud, 13 yang menyatakan bahwa faktor ekonomi (kemiskinan) berkontribusi terhadap kejadian pneumonia balita.

Faktor kondisi rumah yang berhubungan secara bermakna dengan kejadian pneumonia pada balita pada penelitian ini adalah letak/posisi dapur, keberadaan/kebiasaan membuka jendela dan ventilasi kamar tidur. Adanya risiko pneumonia pada balita di rumah dengan letak dapur tidak terpisah dengan ruangan lainnya (OR $=1,40$ ) sangat memungkinkan, mengingat ruang dapur merupakan sumber pencemaran udara dalam ruang rumah. Selama memasak terjadi emisi berbagai bahan pencemar, baik berasal dari pembakaran tidak sempurna dari bahan bakar biomassa (kayu, jerami, batu bara) maupun penguapan dari bahan makanan yang dimasak. Kegiatan memasak dilakukan secara terus menerus (setiap hari) dalam waktu yang cukup lama sehingga asap dari dapur akan mencemari seluruh ruangan, termasuk kamar tidur tempat anggota keluarga lebih banyak menghabiskan waktunya pada malam hari.

Walaupun hasil analisis multivariat, penggunaan bahan bakar untuk memasak tidak berhubungan secara bermakna, tetapi hasil analisis bivariat menunjukkan bahwa penggunaan bahan bakar tidak aman (minyak tanah, kayu bakar, briket batubara) mempunyai risiko terhadap pneumonia balita $(\mathrm{OR}=1,30)$. Hal ini didukung oleh penelitian Ezzati dan Kammen, ${ }^{14}$ yang menyatakan bahwa pajanan terhadap partikel debu dari pembakaran biomassa berhubungan dengan terjadinya infeksi saluran pernafasan akut. Demikian juga hasil penelitian Wichmann dan Voyi, ${ }^{15}$ yang menunjukkan bahwa anak-anak yang rumah tangganya menggunakan bahan bakar yang dapat menimbulkan pencemaran mempunyai risiko pneumonia 1,27 kali dibanding dengan yang menggunakan listrik atau gas.

Adanya risiko pneumonia pada balita tinggal di rumah dengan ventilasi yang tidak memenuhi syarat dan tidak ada atau tidak biasa membuka jendela (OR masingmasing 1,17 dan 1,16) disebabkan karena ventilasi dan jendela mempunyai fungsi sangat penting untuk menjamin kualitas dan kecukupan sirkulasi udara yang keluar dan masuk dalam ruangan rumah. Kurangnya/tidak cukup ventilasi $(<10 \%$ luas lantai ruangan) dan rumah tidak mempunyai/tidak biasa membuka jendela akan membuat bahan pencemar berada dalam ruangan lebih lama sehingga akan menambah risiko pajanan terhadap bahan pencemar di dalam ruang-an. Hasil analisis ini tidak jauh berbeda dengan hasil penelitian Padmonobo, ${ }^{16}$ yang menyatakan bahwa ventilasi rumah merupakan faktor risiko kejadian pneumonia pada anak balita dengan OR sebesar 2,21.

Berdasarkan tipe tempat tinggal, balita yang tinggal di perdesaan mempunyai risiko yang lebih besar mengalami pneumonia dibandingkan dangan balita di perkotaan. Hal ini berhubungan dengan kondisi rumah (jenis lantai, jenis dinding, keberadaan plafon/langit-langit, kepadatan hunian) dan penggunaan bahan bakar yang berbeda antara pedesaan dan perkotaan. Berdasarkan laporan Riskesdas tahun 2013, proporsi rumah tangga yang menggunakan bahan bakar tidak aman di pedesaan $(54,0 \%)$ lebih tinggi dibandingkan di perkotaan $(18,1 \%){ }^{3}$ Walaupun analisis multivariat tidak menunjukkan hubungan yang bermakna antara penggunaan bahan bakar dengan kejadian pneumonia, tetapi hasil analisis bivariat menunjukkan hubungan yang bermakna.

Dari hasil analisis multivariat, jenis bahan bangunan rumah, jenis lantai, jenis dinding, jenis/keberadaan atap plafon/langi-langit bukan merupakan faktor determinan dari pnemonia pada balita, tetapi hasil analisis bivariat menunjukkan hubungan yang bermakna. Balita yang tinggal di rumah dengan lantai tanah, dinding bukan tembok, atap rumah tidak berplafon/langit-langit mempunyai risiko yang lebih besar terhadap pneumonia.

Rumah dengan lantai yang terbuat dari tanah, dinding bukan tembok, dan atap tidak dipasang plafon/langitlangit menyebabkan ruang rumah menjadi panas, berdebu, dan menjadi lebih lembab. Suhu yang panas dapat meningkatkan penguapan di dalam ruangan sehingga tidak hanya kelembaban yang meningkat tetapi juga kandungan pencemar yang berasal dari bahan bangunan rumah. Kelembaban yang tinggi ( $>80 \%$ ), yang berarti kandungan uap air di udara cukup tinggi, merupakan kondisi yang baik untuk pertumbuhan dan kelangsungan hidup sel bakteri (pneumococus) sehingga bakteri dapat tumbuh dengan cepat. ${ }^{17}$ Hal ini didukung oleh hasil penelitian Lystiowati, ${ }^{8}$ yang menyebutkan bahwa suhu dan kelembaban yang tidak memenuhi syarat kesehatan dapat meningkatkan risiko pneumonia balita, masingmasing sebesar 6,79 dan 9,44 kali.

Analisis bivariat juga menunjukkan bahwa kepadatan hunian yang buruk meningkatkan risiko pneumonia pada balita, hal ini karena tingkat kepadatan hunian yang tidak memenuhi syarat disebabkan karena luas rumah 
yang tidak sebanding dengan jumlah anggota rumah tangga yang menempatinya. Rumah yang padat penghuni memungkinkan penularan bakteri, virus penyebab penyakit pneumonia melalui pernapasan dari penghuni rumah yang satu ke penghuni rumah lainnya dengan mudah dan cepat. Hasil analisis pada penelitian ini sesuai dengan hasil penelitian Cardoso dkk, ${ }^{18}$ dan Yuwono, ${ }^{19}$ yang menyatakan bahwa rumah yang tidak memenuhi syarat kepadatan mempunyai risiko terhadap pneumonia (OR masing-masing 2,5 dan 2,7).

Adanya perbedaan nilai OR hasil analisis multivariat pada penelitian ini dengan hasil penelitian yang telah dilakukan sebelumnya, kemungkinan disebabkan karena adanya perbedaan dalam variabel yang diikutsertakan dalam analisis. Fekadu dkk, ${ }^{20}$ dalam analisisnya mempertimbangkan faktor kurang gizi dan membawa anak ketika memasak di samping faktor kondisi fisik rumah dan karakteristik individu. Rudan, ${ }^{21}$ dalam analisisnya memasukkan faktor risiko ASI eksklusif, gizi, pencemaran udara dalam ruangan, berat badan lahir rendah, kepadatan hunian dan kurangnya imunisasi campak. Demikian juga Sugihartono dkk, ${ }^{22}$ mempertimbangkan status imunisasi dan sejarah menyusui, disamping faktor kondisi rumah, penggunaan bahan bakar, adanya anggota keluarga merokok.

\section{Kesimpulan}

Kejadian pneumonia pada anak balita berdasarkan diagnosis oleh petugas kesehatan maupun gejala yang dirasakan/diamati sebesar 4\%. Berdasarkan hasil analisis multivariat, faktor-faktor yang berpengaruh terhadap pneumonia pada balita adalah jenis kelamin, tipe tempat tinggal, pendidikan ibu, tingkat ekonomi/kuintil indeks kepemilikan, letak dapur, keberadaan/kebiasaan membuka jendela dan ventilasi kamar tidur. Hal ini berarti bahwa faktor sosial, demografi, ekonomi dan lingkungan rumah secara bersama-sama berperan terhadap kejadian pneumonia pada balita di Indonesia.

\section{Saran}

Untuk mengendalikan kejadian pneumonia pada balita, intervensi yang dapat dilakukan adalah memperbaiki kondisi fisik rumah seperti pemisahan dapur dengan ruangan lain, memasang ventilasi kamar, dan selalu membuka jendela kamar tidur.

\section{Daftar Pustaka}

1. Unicef/WHO. Pneumonia: the forgotten killer of children. Geneva: The United Nations Children's Fund/World Health Organization; 2006.

2. Kementerian Kesehatan Republik Indonesia. Laporan riset kesehatan dasar 2007. Jakarta: Badan Penelitian dan Pengembangan Kesehatan, Kementerian Kesehatan Republik Indonesia; 2007.

3. Kementerian Kesehatan Republik Indonesia. Riset kesehatan dasar 2013. Jakarta: Badan Penelitian dan Pengembangan Kesehatan,
Kementerian Kesehatan Republik Indonesia; 2013.

4. Badan Pusat Statistik, Badan Kependudukan dan Keluarga Berencana Nasional, Departemen Kesehatan. Survei demografi dan kesehatan Indonesia 2007. Jakarta: Badan Pusat Statistik, Badan Kependudukan dan Keluarga Berencana Nasional, Departemen Kesehatan; 2013.

5. Kementerian Kesehatan Republik Indonesia. Pedoman pengendalian infeksi saluran pernafasan akut. Jakarta: Direktorat Jenderal Pengendalian Penyakit dan Pengendalian Lingkungan, Kementerian Kesehatan Republik Indonesia; 2012.

6. World Health Organization. Pneumonia. Fact sheet N`331 [cited 2013 Nov 13]. Available from: http://www.who.int/mediacentre/factsheets/fs331/en/2013.

7. Azhar K, Perwitasari D. Kondisi fisik rumah dan perilaku dengan prevalensi TB paru di Provinsi DKI Jakarta, Banten, dan Sulawesi Utara. Media Litbangkes. 2013; 23 (4):172- 81.

8. Tana L, Delima, Kristanto AY. Peranan penggunaan bahan bakar terhadap katarak pada ibu rumah tangga di Indonesia. Majalah Kedokteran Indonesia. 2009; 59(8): 363-9.

9. Listyowati. Hubungan kondisi lingkungan fisik rumah dengan kejadian pneumonia pada balita di wilayah kerja puskesmas Tegal Barat, Kota Tegal. Jurnal Kesehatan Masyarakat [online]. 2013 [diakses tanggal 15 Mei 2013]. Diunduh dalam: http://ejournals1.undip.ac.id/index.php/ $\mathrm{jkm}$.

10. Kementerian Kesehatan Republik Indonesia. Riset kesehatan dasar, laporan akhir tahuin 2010. Jakarta: Badan Penelitian dan Pengembangan Kesehatan, Kementerian Kesehatan Republik Indonesia; 2010.

11. Mosley WH, Chen LC. Analytical framework for the study of child survival in developing countries. Population and Development Review. 1984;10 (Issue Supplemen): 25-45.

12. Hananto M. Analisis risiko yang berhubungan dengan kejadian pneumonia pada balita di 4 Provinsi di Indonesia [tesis]. Depok: Fakultas Kesehatan Masyarakat Universitas Indonesia; 2004.

13. Machmud R. Pengaruh kemiskinan keluarga pada kejadian pneumonia balita di Indonesia. Kesmas Jurnal Kesehatan Masyarakat Nasional. 2009; 4(1): 36-41.

14. Ezzati M, Kammen DM. Quantifying the effects of exposure to indoor air pollution from biomass combustion on acute respiratory infections in developing countries. Journal of Environmental Health Perspectives. 2001; 109 (5): 481-8.

15. Wichmann J, Voyi KVV. Impact of cooking and heating fuel use on acute respiratory health of preschool children in South Africa. The Southern African Journal of Epidemiology and Infection. 2006; 21(2): 48-54.

16. Padmonobo H, Setiani O, Joko T. Hubungan faktor-faktor lingkungan fisik rumah dengan kejadian pneumonia di wilayah kerja Puskesmas Jatibarang, Kabupaten Brebes. Jurnal Kesehatan Lingkungan Indonesia. 2012; 11(2): 190-8.

17. Gould D, Brooker C. Mikrobiologi terapaan untuk perawat. Jakarta: EGC 2003.

18. Cardoso MRA, Cousens SN, de Goes Siqueira LF, Alves FM, D’Angelo LA. Crowding: risk factor or protective factor for lower respiratory disease in developing countries. BMC Public Health. 2004; 3 (4): 19.

19. Yuwono TA. Faktor-faktor lingkungan fisik rumah yang berhubungan dengan kejadian pneumonia pada anak balita di wilayah kerja Puskesmas Kawunganten Kabupaten Cilacap [tesis]. Semarang: 
Universitas Diponegoro; 2008.

20. Fekadu GA, Terefe MW, Aleme GA. Prevalence of pneumonia among under five children in Este Town and the surrounding rural Kebeles, Northwest Ethiopia; A Community Based Cross Sectional Study. Science Journal of Public Health [serial on internet]. 2014 [cited 2014 Jan 5]; 2 (3): 150-5. Available from: http://www.sciencepublishinggroup. $\mathrm{com} / \mathrm{j} / \mathrm{sjph}$
21. Rudan I, Boschi-Pinto C, Biloglav Z, Mulholland K, Campbell H. Epidemiology and etiology of childhood pneumonia. Bulletin of the World Health Organization. 2008; 86 (5): 408-16.

22. Sugihartono, Rashmatullah P, Nurjazuli. Analisis faktor risiko kejadian pneumonia pada baliota di wilayah kerja Puskesmas Kota Pagar Alam. Jurnal Kesehatan Lingkungan Indonesia. 2012; 11(1): 82-6. 